\author{
Vaida Misevičiūtè \\ Vytautas Magnus University, Lithuania
}

\title{
A DESPERATE CALL FOR PROCESS AND POST-PROCESS APPROACH IN LITHUANIAN ESL CLASSROOMS
}

Summary. Technology has altered communication style from face to face to written communication. An increased participation in chats, blogs, and other forms of social media along with a growing trend to work from home or to study on-line has increased the need to perfect academic written communication. Lithuanian students who have been trained in product approach are in desperate need to enhance skills in creativity, selfexpression, independence and criticality, skills that can be taught through a process or a post-process approach to writing. An overview of product, process, and post-process approach suggests that second language learners trained in process or post-process approach display significant advantages in academic writing compared to students trained in product approach. Writing has been neglected as a skill for several reasons in Lithuanian English classrooms, yet the demand for academic writing in today's world is increasing in accelerated speed. Process and post-process approach provides necessary skills that have been highly neglected in ESL teaching in Lithuanian schools and universities.

Keywords: product approach; process approach; post-process approach.

\section{Introduction}

116 minutes per day on average was spent by global Internet users on social media blogging, chatting, commenting on pictures or YouTube videos, or negotiating in on-line games and social networks in 2017 (Asano, 2017). These numbers translate to two hours of written communication a day per global citizen or more specifically over 60 billion messages per day, accounting for 10 to 15 messages per person (Smith, 2018). Realistically, it is the millennials who drive this statistic up in developed countries, so it would be fair to double those numbers regarding the millennials. Similarly, in Lithuania, about $89 \%$ of 15-29-year olds use social media daily, writing mostly on Facebook and Instagram, but also other less popular sites like Twitter, Spotify, or Pinterest (Kantar TNS, 2017). This fact followed by such trends as high demand for distance education and home office jobs has further been altering communication style. Written communication is preferred over face to face 
communication at home, in the offices, and even schools. Most of the professional communication today is carried out through writing, and failure to express ideas well through writing has direct negative consequences in life. It is important to acknowledge that our generation writes more than any other generation ever did. The aim of this article is to draw attention to the need for academic writing courses in Lithuania.

While considering the need for written communication, it is really important to stress that most of the written communication happens in English. English dominates social media and has become a Lingua Franca of global sharing (Ferguson, 2012). Therefore, negotiating, sharing ideas, and creating common knowledge with global citizens puts very high demands on written competence. Culturally diverse content on social media additionally demands for an advanced level in tolerance, criticality, and sensitivity to cultural differences. Writing instructors need to educate the young second language learners to write responsibly to assure that such sharing does not promote conflict on social media but inspires learning and positive changes around the world.

Research studies on social media and writing often focus on English habits and are rather conflicting. There are those who claim that social media turned writing into a simplified system of abbreviations and colloquialisms; however, on the other hand, and especially among English as a second language learners, writing on social media is claimed to allow writers to present their thoughts freely and critically, reflect on various readings, argue with peers, and therefore, deepen their critical thinking, acquire higher level of cognitive skills, increase academic English vocabulary, and co-construct knowledge about academic writing (Bloch, 2007; Sun \&Chang , 2012; Ware, Kern, Warschauer, 2016; Zeng, Yim, Warschauer, 2017).

The goal here is not to discuss the influence of social media onto writing even though Miliūnaitè (2014) reports the "decline in literacy" in Lithuanian student writing along with some "crucial changes connected to the quality of language used and pupils' incapability to take full advantage of the opportunities offered by language" (16). Rather, it is to draw attention that social media has turned everyone into writers. With one click, a message gets sent for the whole world to scrutinize, evaluate, and judge. A message, often without a possibility to be deleted, edited, or rewritten, remains there for 
generations to see. To prevent wasteful writing on social media, teaching how to write responsibly, properly, and with a purpose should be one of the most important tasks in schools today. After all, learning to write in academic L2 (second language) prose requires advanced linguistic foundations that may not be possible without explicit, focused, and consistent instruction of grammar, vocabulary, and discourse (Hinkel, 1999; Johns, 1997; Celce-Murcia, 1991; Ellis, 2002, De Freitas Villas Boas, 2014; Xu\&Li, 2018). This significant and current research into the need for proper academic writing instruction is noteworthy not only to Lithuanians, but it is in demand in many countries that focused highly on process approach.

\section{Problem}

The problem is that in Lithuania written communication in English is not a top priority in schools or universities. Many Lithuanian students possess high English competence though standardized testing. Mostly standardized testing evaluates students' inactive skills such as vocabulary, reading comprehension and grammatical knowledge; unfortunately, this score does not truly reflect practical knowledge needed to carry academic tasks, especially writing tasks. Jim Cummins (2016) has advanced and refined his research on academic English and concluded that many students may appear fluent in English (master basic interpersonal communication skills (BICS) but have gaps in mastery of cognitive academic language proficiency (CALP). Most researchers agree that people in intensive English programs may acquire conversational English or BICS in 2 years, but the academic language or CALP may take 5 to 7 years. As the hardest skill, written language may take about 10 years to master (Collier, 1989; Cummins, 2016; Hakuta et al, 2000). Since these authors are mainly talking about intensive English classes, written communication requires a lot of deliberate attention. It is my strong belief that process and post-process approach to writing is desperately needed in Lithuania to assure that students can enhance academic writing skills, and they can take full advantage of the benefits social media can offer. 


\section{Theoretical background}

\section{Product Approach}

Product approach in writing is the oldest academic writing approach. The main features of the product approach are imitation of a perfect scholarly text including mimicry of the standard organization (like introduction, theoretical background, methods, discussion, results, and conclusion) and emphasis on the final product and one draft (students, in academic context for example, cannot revise or improve the text and are usually evaluated on the final product). In other words, writing has never been looked as a necessary discipline. Simply, students had to learn to write by themselves by imitation. This approach has been favored in various academic disciplines for centuries because professors cared about their subject and not principles of writing. Behaviorist theories which influenced most disciplines including writing proclaimed that by reading academic texts, students would learn to produce equally successful ones by trial and error. A writing sample was never viewed as a draft. It was viewed as a final product. In addition, until 1960's academic writing was mostly associated with literary analysis. Teachers were trained in literary analysis rather than an actual writing process. Such approach of teaching writing was called "traditional paradigm" (Hairston, 2002) or "product approach" because the teachers looked at the final product without paying attention to how the result was achieved (Kroll, 1991).

Research into writing, especially writing in a second language in Lithuania is limited; however, the existing ones and even the most current ones point to the same inability to write well. Specifically, Žindžiuvienè (2003) concludes that Lithuanian students at school and even the first years in the university do not have good foundations in writing instruction; therefore, students' ideas remain fragmented and critically inadequate. Furthermore, without structured writing instruction students are not given any tools to become independent and confident in academic writing (20). Not only is product approach frustrating to the professors, it is as exasperating to the students because they often have no idea how to achieve a perfect result 
(Lindemann, 1995). Hundreds of years of training in such tradition has created many problems and often fear of writing.

Some of the bad habits that have been described in research studies are exactly those that make writing of Lithuanian students weak. Firstly, product approach encourages students to imitate texts of other scholars killing independent thought (Badger and White, 2000). This leads to serious problems with plagiarism. Students are trained to borrow ideas and steal beautiful phrases without much consideration or understanding that this is somehow wrong. Furthermore, product approach has also been criticized for lack of creativity and freedom it offers learners to produce their own ideas, to revise and reinvent ideas through collaboration. Prodromou (1995) declared plainly that product approach devalued "the learners' potential, both linguistic and personal." These drawbacks are painfully obvious in Lithuanian writing, one example of which can be a recent scandalous plagiarism case of P. Baršauskas dissertation (Office of Ombudsman for Academic Ethics and Procedures of the Republic of Lithuania, 2017).

Therefore, a process or post-process approach to academic writing is needed in Lithuania because many students do not view academic writing as a long time-consuming process in need of editing and revision. It seems that majority of Lithuanian students today tend to believe that academic work is a final product, something cut in stone, a product that does not need to be revised or edited, and, especially if submitted for grading or publication, it is a perfect end product that will not or cannot change over time. As Scollon (1999) noted, in many product approach cultures, by virtue of writing, the author gains undisputable credibility and recognition, and the texts are undisputable because they stood the test of time. Consequently, a lot of students in classes do not consider revision as a necessary step in writing. Even worse, if the teacher introduces peer review, a common activity that process approach teachers apply to allow students to find flaws in writing among equal peers, they consider it as a waste of time and devalue any criticism from peers. According to Česnienè (2015) peer-review is a scarcely used activity among Lithuanian educators and the value of peer-review is "often underestimated because teachers tend to undervalue students' abilities as both writers and reviewers." Students, however, also do not value the suggestions or criticism received (71). In contrast, in an Anglo-American tradition of writing, authorities 
are made not by virtue of status but by standing up to criticism within a peer group which is often achieved through multiple argumentative pieces and comments to peer criticism and reviews (Belcher \&Braine,1995). Peer criticism and revision is as natural as drinking water, and by default, the more a person revises his/her work, the more competent the writing.

\section{Process Approach versus Post- process Approach}

To solve a great number of the problems discussed above, a process approach was invented. Process approach revolutionized writing instruction in 1960's. Janet Emig, James Britton and his colleagues in Britain's School Council Project, the Development of Writing Abilities are often cited as pioneers of the new "process approach" (Kroll, 1991; Lindemann, 1995). The major claims coming from their research declared that all writers had to go through: brainstorming, listing, free writing, clustering, outlining, writing and re-writing (revising), and finally editing. Therefore, the process approach focused on the strategies to help students write across different rhetorical patterns, and the strategies to understand their goals and their audience. In addition, process approach tried to instill the idea that ideas in writing can be changed, negotiated, and improved through constant discussion with peers and teachers. ESL professionals quickly adopted these findings to teaching ESL because this seemed as a great way to help students understand HOW to write. Starting with the 1960's most of the ESL textbooks were published with the focus on the process. Writing books taught students to practice most commonly used rhetorical modes in writing-cause or effect, argumentative, comparative, narrative, or process.

Today, however, process pedagogy has been criticized. Many researchers reject process pedagogy in writing claiming that process approach shifted the focus from the critical ideas in academic writing to an overestimated praise of writing behaviors. In the late 1990's, a new movement, a "post process pedagogy" was born. Many post-process scholars drew attention to this oversimplification of writing (Kent, 1999; Pullman, 1999). They claimed that process pedagogy reduced writing to a "series of confined phrases" and 
created "a series of generalizations about writing that supposedly hold true all or most of the time" (Breuch, 2003, p. 97).

Partially, this criticism of process approach is very true. Twenty years of reading essays by non-native speakers who were trained in process approach only, showed many flaws in writing. Students are fairly quick in memorizing hedges and formulaic topic sentences, they easily figure out the importance of thesis statement, and the opposing view structures. They master the formula and the essay looks perfectly organized. Many students are smart enough to add one or two perfectly memorized complex grammatical sentences to score fairly high on a TOEFL exam, yet once faced with complex academic tasks in the universities where teachers demand to analyze examples, readings, compare and contrast of synthesize information, those perfectly organized essays no longer bring them high marks.

Despite the criticism for process approach, I strongly suggest that process of writing be introduced. Process approach instills some very good habits that only later need to be supplemented by more advanced ideas. In fact, process pedagogy proponents today are mostly foreign scholars who continue to see enormous benefits in teaching how to write second language learners through a process. Many conclude that process approach has enhanced students' ability in organizing ideas, formatting papers, and even improving support due to multiple drafts (De Freitas Villas Boas, 2014; Arteaga-Lara\&Mauricio, 2017; Xu \&Li, 2018; Žindžiuvienè, 2003). Therefore, it is very important to continue to use the process approach in academic writing, but at the same time it is imperative not to forget the critical purpose of academic writing, therefore, to take the best points from post-process approach.

Another reason why Lithuanian students desperately need training in academic writing in this case focuses more on the post-process approach which gives emphasis to an enhancement of criticality and academic vigor in writing. Having scrutinized academic writing samples of second language learners from around the world in the USA universities for over twenty years, an inevitable conclusion comes to mind-majority of students not trained in process or postprocess approach have difficulties in narrowing down a topic, supporting ideas with adequate and specific examples/knowledge or data, and in writing with a clear purpose in mind. 
To be more specific, many second language learners trained in product approach feel huge pressure while writing in English. They typically do not trust their own ideas as valuable, and wanting to produce perfect scholarly articles due to limited vocabulary and grammar often fall for the wrong strategies like plagiarism or very awkward translation. Since writing traditions are different around the world, and different strategies are valued, students often cannot succeed without explicit instruction on cultural rhetoric. For example, in Confucian tradition, vagueness and ambiguity is valued in writing (Hirokawa\& Swales, 1986) with scholarly and scientific voice (Scollon, 1996; Leki, 1995), yet in Anglo-American tradition objectivity is valued with "overt, expressive, assertive, and even demonstrative" voice (Atkinson, 2016, p. 551). Similarly, the differences in writing tradition were acknowledged by Žindžiuvienè (2003). She claims that English textbooks often have their own learning agenda and values different from Lithuanian ones, and teachers often fail to take into account the questions of language interference and transposition" (24). These differences in academic expectations are essential in knowing how to participate in academic written circles successfully, and therefore, an explicit instruction is desperately needed in Lithuanian classrooms.

For example, in one of the academic English classes at $\mathrm{C} 1$ proficiency level, 20 Lithuanian second year university students were asked to write a travel blog on Padlet, a social media site. They were asked to describe ONE travel destination of their choice in two paragraphs emphasizing a unique feature of that place. The students were warned not to exceed the limit and focus on ONE unique feature. In addition, students were warned not to fall into the trap of listing one activity after another without any details, and were provided with 3 unique travel blogs that emphasized such focus on a unique observation. In fact, the task was not focusing on the process approach. Rather, students were given a task and demanded to produce a final product. Out of 20 students, only 5 students were able to narrow the topic down to one city, and only 3 students were able to pick out one unique feature and describe it appropriately. The other fifteen students followed a disorganized "dream of consciousness" approach that is very typical for product approach. Furthermore, lack of planning and topic sentences (that often limit the writing) allowed many digressions that had nothing to do with the description of the city. The two successful posts came from students who were exposed to 
process or post-process approach through Erasmus+ exchange in English speaking countries. A simple analysis of a casual classroom activity revealed severe drawbacks in student writing.

One serious drawback in writing that post-process approach could help second language learners understand is that writing is a social activity. Because social media is an essential part of students' life, an understanding that writing lives beyond the walls of the classroom and that the teacher is not the only authoritative audience "can help L2 writers regard writing as a social discursive phenomenon and perform the act of writing as sociocultural action for betterment of their lives" (Kalan, 2014). Such realization helps students reevaluate the purpose of writing, look at writing more critically and responsibly because the critics become their peers, and often native speakers. Another important point that post-process approach could help understand is that every student has a unique and interesting perspective and copying the ideas of others does not create interest or novelty. Post-process approach values independent thought. An awareness that not all writing demands the same rigor and obedience to follow overpraised writing rules and dominant tradition can help student feel more confident and trust themselves and their thinking. Experimenting with ideas and ways of presenting them is a very important part of writing. Students should be allowed to write and rewrite and revise ideas, question old fashioned rules, and create new ways of academic communication that encompasses writing traditions that have not been privileged but have the same right to be accepted and respected. Furthermore, there are different genres that can be just as critical and important as quantitative or qualitative research papers. Students, from a post-process perspective, gain genre awareness that can help understand existing and dominant genres in writing (Breuch, 2013; Hyland, 2003; Kalan, 2014). The claims of post-process approach scholars are significant in predominantly Anglo-American writing style. However, at this point it is important to note that when students do not have the experience or knowledge to analyzing their own cultural writing, they do not have the ability to evaluate different possibilities, or do not even understand that there is a dominance in writing and it needs to be questioned.

No doubt, the issues raised here with post- process approach may seem somewhat too advanced for ESL classrooms in Lithuania. First, they need 
to be trained in the process approach to understand HOW writing is done, and only then slowly be introduced to the dominance and privilege of academic circles. However, Lithuania as a small country cannot stay behind the progressive ideas in critical pedagogy. Considering how overwhelmingly popular social media and written communication is today, it is inevitable that teachers introduce writing classes adopting this approach in ESL classrooms in Lithuania. Even though post-process approach has not been found to have superior advantage over process approach, yet "they both indicated remarkable priority over product approach (Hashemnezhad, 2012). Considering advantages and disadvantages of all the methods in writing, it is really important to work on the critical aspect of student writing.

Yet another significant reason why process approach to academic writing is needed in Lithuania is due to the fact that writing has been neglected in language teaching. Several reasons for this neglect can be observed. On one hand, English pronunciation, listening, speaking, grammar, writing, and reading have been taught together. Covering all six skills in one 45-minute lesson is not viable. On the other hand, writing has lost its battle in the fight of importance. English competence is measured by standardized tests in Lithuania, so it naturally dictates that grammar and vocabulary be taught as a priority. Furthermore, high demand for proficient English speakers in the past 20 years focused teachers' attention onto native like pronunciation and fluent speech.

Finally, an apparent neglect to process writing stems from the time needed to read several drafts, comment on them, and grade them. For example, in USA, many English as a second language programs separate teaching skills into reading, writing, speaking, listening and grammar or at least in listening-speaking and reading-writing. Typically, most ESL teachers get specialized into teaching only those skills, and for sure there are those who flourish in teaching of writing only. A full-time writing teacher will get a maximum of three classes per semester of which 2 at the most will be writing classes. Their task is to focus purely on writing during one semester. In a twelve week semester, students will typically write 3 papers; each paper with three drafts. In many intensive ESL programs teachers will have 10 to 15 students, so they will read, comment, and grade about 180 papers per semester. Even though the work is intensive and demanding, teachers can and 
do help students to focus and improve their academic writing. In contrast, writing in Lithuanian English classroom is a suicide to a teacher. A typical English classroom has about 20 students, and a full time ESL teacher will teach about 6 classes per semester. The teachers are responsible for all 6 skills in one semester; therefore, if a teacher wanted to include one serious writing assignment per class with a process approach, he or she would have to read 240 papers per semester not to mention grammar tests, evaluation of presentations, and other tasks that are required in combined skills classroom. This insane amount of work makes writing a highly unpopular skill in ESL classroom in Lithuania. In addition, if the students get to experience only one paper per semester, they are not getting a full advantage of learning how to improve their thoughts, their organization, critical thinking, and revision or editing process.

\section{Conclusions}

Considering how much time people have to write in today's world, it is essential to offer academic writing instruction to students. Product approach devalues critical thought and encourages plagiarism through imitation. Product approach does not promote revision and respect for peer criticism which are essential elements in academic writing. Lithuanian students display typical problems to students trained in product approach; namely, inability to narrow down ideas, present specific examples, analyze information, and write with a purpose in mind. Current research shows significant improvement in writing and criticality when ESL students are trained through process or post-process approach.

Furthermore, it is claimed that only explicit and deliberate instruction in writing can help students effectively participate in academic writing tasks. Process and post-process approach is vital in teaching students to write well academically. After all, no one will deny that it is much more pleasant to read a well-organized article than a "stream of consciousness" publication or even a blog. Even if we know that today social media has simplified grammar and reduced writing standards, even if we know that many scholarly publications do not follow a clear formula in writing, it is no reason to stop preparing students to write well. Considering how important writing is in today's world, it 
is a crime to neglect writing as a skill in ESL classrooms. ESL students already have a disadvantage in their limited use of vocabulary and grammar compared to native speakers, so why not teach them through process and post-process approach to give them an advantage in organizing and supporting their ideas. Process along with post-process approach is desperately needed in Lithuania.

\section{References}

Asano, E. (2017). How Much Time Do People Spend on Social Media? Infographic.

Retrieved

from

https://www.socialmediatoday.com/marketing/how-much-time-dopeople-spend-social-media-infographic.

Atkinson, D. (2016). Second Language Writing and Culture. In R. M. Manchón \& P. K. Matsuda (Eds.), Handbook of Second and Foreign Language Writing (pp. 545-566).

Arteaga-Lara, H. M. (2017). Using the Process-Genre Approach to Improve Fourth-Grade EFL Learners' Paragraph Writing. Latin American Journal of Content and Language Integrated Learning, 10(2), 217-244.

Badger, R. \& G. White. 2000. A process genre approach to teaching writing. ELT Journal, 54(2), 153-160.

Belcher, D., \& Braine, G. (1995). Academic Writing in a Second Language: Essays on Research and Pedagogy. Ablex Publishing Corporation.

Bloch, J. (2007). Abdullah's Blogging: A Generation 1.5 Student Enters the Blogosphere. Language Learning \& Technology, 11(2), 128-141.

Breuch, L. K. (2003). Post-Process 'Pedagogy': A Philosophical Exercise. In V. Villanueva \& K. L. Arola (Eds.), Cross-Talk in Comp Theory: A Reader (pp. 97-125).

Celce-Murcia, M. (2000). Teaching English as a Second or Foreign Language (3rd ed). Heinle \& Heinle.

Collier, V. P. (1989). How Long? A Synthesis of Research on Academic Achievement in a Second Language. TESOL Quarterly, 23(3), 509-531. Cummins, J. (2016). Reflections on Cummins (1980), The Cross-Lingual Dimensions of Language Proficiency: Implications for Bilingual 
Education and the Optimal Age Issue. TESOL Quarterly, 50(4), 940944. DOI https://doi.org/10.1002/tesq.339.

Česnienè, Z. (2015). Rašymo igūdžiu tobulinimas taikant studentu tarpusavio vertinimo metoda. Pedagogy, 120(4), 61-72

De Freitas Villas Boas, I. (2014). Process Writing in a Product-Oriented Context: Challenges and Possibilities. Revista Brasileira de Lingüística Aplicada, 14(2), 463-490.

Ellis, R. (2002). The Place of Grammar Instruction in the Second/Foreign Curriculum. In E. Hinkel \& S. Fotos (Eds.), New Perspectives on Grammar Teaching in Second Language Classrooms (pp. 17-34).

Ferguson, G. (2012). Barbara Seidlhofer: Understanding English as a Lingua Franca. Oxford University Press, 2011. Applied Linguistics, 33(4), 463465.

Hairston, M. (2002). The Winds of Change: Thomas Kuhn and the Revolution in the Teaching of Writing. In D. Jolliffe, D. Keene, M. Trachsel, \& R. Voss (Eds.), Against the Grain: A Volume in Honor of Maxine Hairston (pp. 29-44).

Hashemnezhad, H. (2012). A Comparative Study of Product, Process, and Post-process Approaches in Iranian EFL Students' Writing Skill. Journal of Language Teaching and Research, 3(4), 722-729. DOI doi:10.4304/jltr.3.4.722-729.

Hakuta, K, Butler, Y.G., Witt, D. (2000). How Long Does It Take English Learners to Attain Proficiency? The University of California Linguistic Minority Research Institute. Policy Report 2000-2001. Retrieved from https://web.stanford.edu/ hakuta/Publications/\%282000\%29\%20\%20HOW\%20LONG\%20DOES\%20IT\%20TAKE\%20ENGLISH\%20LEA RNERS\%20TO\%20ATTAIN\%20PR.pdf.

Hinkel, E. (2004). Teaching academic ESL writing: practical techniques in vocabulary and grammar. Mahwah, N.J.: L. Erlbaum Associates.

Hirokawa, K., \& Swales, J. (1986). The Effects of Modifying the Formality Level of ESL Composition Questions. TESOL Quarterly, 20(2), 343-345.

Hyland, K. (2003). Genre-based pedagogies: A social response to process. Journal of Second Language Writing, 12(1), 17-29. doi:10.1016/S1060-3743(02)00124-8 
Johns, A. M. (1997). Text, role, and context: developing academic literacies. New York: Cambridge University Press.

Kalan, A. (2014). A Practice-Oriented Definition of Post-Process Second Language Writing Theory. TESL Canada Journal, 32(1), 1-18.

Kantar TNS. (2017). Žiniasklaidos tyrimu apžvalga 2017. Retrieved from http://www.tns.It/data/files/Metines_apzvalgos/Kantar_TNS_Metinè_ žiniasklaidos_tyrimu_apžvalga_2017m.pdf.

Kent, T. I. (ed. and introd.). (1999). Post-Process Theory: Beyond the WritingProcess Paradigm.

Kroll, B. (1991). Teaching Writing in the ESL Context. In M. Celce-Murcia (Eds.) Teaching English as a second or foreign language (pp. 219232).

Leki, I. (1995). Coping Strategies of ESL Students in Writing Tasks Across the Curriculum. TESOL Quaterly. 29(2), 235-260. DOI doi.org/10.2307/3587624.

Lindemann, E. (1982). Rhetoric for writing teachers. New York: Oxford University Press.

Office of Ombudsman for Academic Ethic and Procedures of the Republic of Lithuania. (2018). Petras Baršauskas violated the law on the Adjustment of public and private interests in the civil service. Retrieved from http://www.etika.gov.lt/2018/01/2018-01-17-petrasbarsauskas-violated-the-law-on-the-adjustment-of-public-andprivate-interests-in-the-civil-service/.

Miliūnaitè, R. (2014). Mokytojai Apie Informaciniu Technologiju Poveiki Mokiniu Raštingumui. Bendrinè Kalba, 87, 1-16.

Prodromou, L. (1995). The backwash effect: from testing to teaching. English Language Teaching Journal, 21(1), 1-25.

Pullman, G. (1999). Stepping Yet Again into the Same Current. In T. Kent (Ed.), Post-Process Theory: Beyond the Writing-Process Paradigm (pp. 1629).

Scollon, S. (1999). Not to Waste Words or Students: Confucian and Socratic Discourse in the Tertiary Classroom. In E. Hinkel (Ed.), Culture in Second Language Teaching and Learning (pp. 13-27). 
Smith, K. (2018). 121 Amazing Social Media Statistics and Facts. Retrieved from https://www.brandwatch.com/blog/amazing-social-mediastatistics-and-facts/.

Sun, Y.C., Chang, Y.J. (2012). Blogging to Learn: Becoming EF Academic Writers Through Collaborative Dialogues. Language Learning \& Technology, 16(1), 43-61.

Ware, P., Kern, R., \& Warschauer, M. (2016). The development of digital literacies. In P. K. Matsuda \& R. K. Manchón (Eds.), Handbook of second and foreign language writing (pp. 307-28).

Xu, X., \& Li, X. (2018). Teaching Academic Writing through a Process-Genre Approach: A Pedagogical Exploration of an EAP Program in China. TESL-EJ, 22(2), 1-21.

Zheng, B., Yim, S., \& Warschauer, M. (2016). Social Media in the writing classroom and beyond. In J. I. Liontas (ed.), The TESOL Encyclopedia of English Language Teaching.

Žindžiuvienè, I. (2003). Rašomosios anglu kalbos ugdymo paradigmos svarbiausios gairès. In Acta paedagogica Vilnensia, 11, 19-28.

\section{Vaida Misevičiūtè}

Vytauto Didžiojo universitetas, Lietuva; vaida.miseviciute@vdu.It

\section{ŽŪTBŪTINIS POREIKIS İDIEGTI PROCESINĮ AR PO-PROCESINI RAŠYMO METODA ANGLY KALBOS PAMOKOSE LIETUVOJE}

Santrauka. Moderniosios technologijos sparčiai keičia tarpusavio bendravimą bendravimu raštu. Ryškiai padideję̨s dalyvavimas tinklaraščiuose ir kitose socialinès žiniasklaidos formose bei galimybe dirbti iš namu arba mokytis nuotoliniu būdu reikalauja puikiu akademinio rašymo igūdžiu. Kadangi Lietuvoje rašinius mokoma rašyti "produkto" metodu (product approach) t.y. siekiant tobulo rezultato vienu bandymu, yra būtina tobulinti studentu kūrybiškuma, saviraiška, savarankiškumą ir kritinio mastymo igūdžius kuriuos kaip tik skatina procesinio ir po-procesinio rašymo metodai. Produkto, procesinio, ir po-procesinio rašymo metodu apžvalga rodo, kad antrosios kalbos besimokantieji studentai turi akivaizdžiu pranašumu akademinio rašymo srityje palyginti su mokiniais, kurie mokomi pagal produkto metoda. Lietuvoje rašymas anglu kalbos pamokose yra apleistas dèl keliu priežasčiu, tačiau akademinio rašymo poreikis šiuolaikiniame pasaulyje tik dideja. Procesinio ir po-procesinio rašymo metodai yra būtini Lietuvos mokyklose ir universitetuose.

Pagrindinès sąvokos: i produktą orientuotas metodas; i procesą orientuotas metodas; po-procesinis metodas. 